\title{
Role of Central Leptin Signaling in the Starvation-Induced Alteration of B-Cell Development
}

\author{
Miyako Tanaka, ${ }^{1}$ Takayoshi Suganami, ${ }^{1}$ Misa Kim-Saijo, ${ }^{1}$ Chitoku Toda, ${ }^{3}$ Makoto Tsuiji, ${ }^{4}$ Kozue Ochi, ${ }^{1}$ \\ Yasutomi Kamei, ${ }^{1}$ Yasuhiko Minokoshi, ${ }^{3}$ and Yoshihiro Ogawa ${ }^{1,2}$ \\ ${ }^{1}$ Department of Molecular Medicine and Metabolism, Medial Research Institute and ${ }^{2}$ Global Center of Excellence Program, International Research Center \\ for Molecular Science in Tooth and Bone Diseases, Tokyo Medical and Dental University, Bunkyo-ku, Tokyo 113-8510, Japan, ${ }^{3}$ Division of Endocrinology \\ and Metabolism, Department of Developmental Physiology, National Institute for Physiological Sciences, Okazaki, Aichi, 444-8585, Japan, and ${ }^{4}$ Department \\ of Microbiology, Hoshi University, Shinagawa-ku, Tokyo 142-8501, Japan
}

Nutritional deprivation or malnutrition suppresses immune function in humans and animals, thereby conferring higher susceptibility to infectious diseases. Indeed, nutritional deprivation induces atrophy of lymphoid tissues such as thymus and spleen and decreases the number of circulating lymphocytes. Leptin, a major adipocytokine, is exclusively produced in the adipose tissue in response to the nutritional status and acts on the hypothalamus, thereby regulating energy homeostasis. Although leptin plays a critical role in the starvation-induced T-cell-mediated immunosuppression, little is known about its role in B-cell homeostasis under starvation conditions. Here we show the alteration of B-cell development in the bone marrow of fasted mice, characterized by decrease in pro- $B$, pre- $B$, and immature $B$ cells and increase in mature $B$ cells. Interestingly, intracerebroventricular leptin injection was sufficient to prevent the alteration of B-cell development of fasted mice. The alteration of B lineage cells in the bone marrow of fasted mice was markedly prevented by oral administration of glucocorticoid receptor antagonist RU486 (11 $\beta$-[ $p$-(dimethylamino)phenyl]-17 $\beta$-hydroxy-17-(1-propynyl)estra-4,9-dien-3-one). It was also effectively prevented by intracerebroventricular injection of neuropeptide $\mathrm{Y} \mathrm{Y}_{1}$ receptor antagonist BIBP3226 [(2R)-5-(diaminomethylideneamino)-2-[(2,2-diphenylacetyl)amino]- $N$-[(4hydroxyphenyl)methyl]pentanamide], along with suppression of the otherwise increased serum corticosterone concentrations. This study provides the first in vivo evidence for the role of central leptin signaling in the starvation-induced alteration of B-cell development. The data of this study suggest that the CNS, which is inherent to integrate information from throughout the organism, is able to control immune function.

\section{Introduction}

Nutritional deprivation or malnutrition results in neuroendocrine dysfunction, decrease in reproductive and thyroid hormones, and activation of the hypothalamus-pituitary-adrenal axis (Ahima et al., 1996; Chan and Mantzoros, 2005). Such neuroendocrine alteration represents an adaptive response to energy deficiency. It is also known that nutritional deprivation or malnutrition suppresses immune function in humans and animals, thereby conferring higher susceptibility to infectious diseases (Cason et al., 1986; Chandra, 1991). For instance, nutritional deprivation induces atrophy of lymphoid tissues such as thymus

Received Dec. 16, 2010; revised April 13, 2011; accepted April 15, 2011.

Author contributions: T.S. and Y.O. designed research; M.Ta., M.K.-S., C.T., and K.O. performed research; M.Ta., T.S., M.K.-S., C.T., M.TS., Y.K., and Y.M. analyzed data; M.Ta., T.S., and Y.O. wrote the paper.

This work was supported in part by Grants-in-Aid for Scientific Research from the Ministry of Education, Culture, Sports, Science, and Technology of Japan and the Ministry of Health, Labor, and Welfare of Japan, and research grants from Mitsubishi Parma Research Foundation, Kao Research Council for the Study of Healthcare Science, and Takeda Science Foundation. M.Ta. was supported by Mishima Kaiun Memorial Foundation (2005-2006) and Tokyo Biochemical Research Foundation (2008). We thank Dr. Goro Katsuura for technical advice and Ai Togo for secretarial assistance.

The authors declare no competing financial interests.

Correspondence should be addressed to Yoshihiro Ogawa or Takayoshi Suganami, Department of Molecular Medicine and Metabolism, Medical Research Institute, Tokyo Medical and Dental University, 1-5-45, Yushima, Bunkyo-ku, Tokyo 113-8510, Japan.E-mail: ogawa.mmm@mri.tmd.ac.jp or suganami.mmm@mri.tmd.ac.jp.

DOI:10.1523/JNEUROSCI.6562-10.2011

Copyright $\odot 2011$ the authors $\quad 0270-6474 / 11 / 318373-08 \$ 15.00 / 0$ and spleen and decreases the number of circulating $\mathrm{T}$ and $\mathrm{B}$ cells (Chandra, 1991; Lord et al., 1998; Chan et al., 2006).

Leptin, a major adipocyte-derived bioactive substance, is produced in response to the nutritional status and acts directly on the hypothalamus, thereby regulating food intake and energy expenditure (Friedman and Halaas, 1998; Ogawa et al., 1999; Cone, 2006). The leptin receptor is expressed not only in the hypothalamus but also in a variety of peripheral tissues (Friedman and Halaas, 1998). There is considerable evidence that leptin plays a role in the pathophysiology of acute and chronic inflammatory diseases, such as bacterial infection, atherosclerosis, and tissue fibrosis (La Cava and Matarese, 2004; Bodary et al., 2007; Tanaka et al., 2010).

It is known that leptin-deficient $o b / o b$ mice exhibit the immunological changes similar to those induced by starvation, i.e., thymic atrophy and decreased maturation of T and B cells (Howard et al., 1999; Claycombe et al., 2008; Lam et al., 2010). Because serum leptin concentrations are rapidly lowered by starvation (Ahima et al., 1996), it is conceivable that leptin plays a role in the starvation-induced immunodeficiency. Indeed, leptin prevents the starvation-induced immunosuppression, which is mediated by T cells (Lord et al., 1998). There is also in vitro evidence suggesting that leptin can activate cytokine signaling pathway in $\mathrm{T}$ cells, thereby regulating their proliferation and apoptosis (Lord et al., 1998; Palmer et al., 2006). Conversely, little is known about the role of leptin in B-cell development and function. In this 
regard, $o b / o b$ mice exhibit impaired humoral as well as cellular immune responses to experimental arthritis (Busso et al., 2002). ob/ob mice also show impaired B lymphopoiesis in the bone marrow, which is reversed by intraperitoneal injection of leptin, suggesting the role of leptin in B-cell development (Claycombe et al., 2008). However, it is currently unknown whether leptin signaling is involved in B lymphopoiesis under starvation conditions and, if so, how leptin regulates B-cell development in vivo.

Here, we show the alteration of B-cell development in the bone marrow of both fasted mice and $o b / o b$ mice. Notably, such alterations are reversed by central leptin administration. Our data also suggest that corticosterone is involved in the starvationinduced alteration of B-cell development. This study highlights the role of central leptin signaling in B-cell development under starvation conditions, thereby suggesting that the CNS, which is inherent to integrate information from throughout the organism, is able to control immune function.

\section{Materials and Methods}

Reagents. All reagents were purchased from Sigma-Aldrich or Nacalai Tesque unless otherwise noted. Allophycocyanin (APC)-conjugated anti-B220 (clone RA3-6B2) and biotin-conjugated anti-IgD (clone 1126) antibodies and phycoerythrin (PE)-conjugated streptavidin were purchased from eBioscience. PE-conjugated anti-CD43 (clone S7) and FITC-conjugated anti-IgM (clone R6-60.2) were purchased from BD Biosciences Pharmingen.

Animals. Eight-week-old male C57BL/6J-ob/ob and wild-type mice were purchased from Charles River Japan. They were maintained in a temperature-, humidity-, and light-controlled room (12 h light/dark cycles) and allowed ad libitum access to water and standard chow (CE-2; CLEA Japan) unless otherwise noted. All animal experiments were conducted according to the guidelines of the Tokyo Medical and Dental University Committee on Animal Research (publications 0090058, 100098, and 0110003A).

Intraperitoneal injection experiments. Eight-week-old male C57BL/6J wild-type mice were divided into three groups. One group was allowed ad libitum access to chow and received an intraperitoneal injection of 0.2 $\mathrm{ml}$ of PBS at 10:00 A.M. and 7:00 P.M. for 48 h. Two groups were fasted for $48 \mathrm{~h}$, when they received an intraperitoneal injection of $0.2 \mathrm{ml}$ of recombinant mouse leptin $(1 \mu \mathrm{g} / \mathrm{g}$ initial body weight) or PBS at 10:00 A.M. and 7:00 P.M.

Intracerebroventricular injection experiments. Eight-week-old male C57BL/6J wild-type mice were anesthetized with isoflurane, and a cannula was implanted into the lateral ventricle (C315GS-2; Plastics One). Five days after the intracerebroventricular cannulation, mice were divided into three groups. One group was allowed ad libitum access to chow and received an intracerebroventricular injection of $0.5 \mu \mathrm{l}$ of artificial CSF (aCSF) at 10:00 A.M. and 7:00 P.M. for 48 h. Two groups were fasted for $48 \mathrm{~h}$, when they received an intracerebroventricular injection of $0.5 \mu \mathrm{l}$ of recombinant mouse leptin $(0.5 \mu \mathrm{g})$, neuropeptide $\mathrm{Y} \mathrm{Y}_{1}$ receptor $\left(\mathrm{NPY} \mathrm{Y}_{1} \mathrm{R}\right)$ antagonist BIBP3226 [(2R)-5-(diaminomethylideneamino)-2-[(2, 2-diphenylacetyl)amino]- $N$-[(4-hydroxyphenyl)methyl]pentanamide] (10 nmol; Tocris Bioscience), or aCSF at 10:00 A.M. and 7:00 P.M. for $48 \mathrm{~h}$.

Intracerebroventricular injection of leptin to $o b / o b$ mice was performed as described (Satoh et al., 1998; Tanaka et al., 2010). In brief, mice were anesthetized with isoflurane, and a cannula was implanted into the lateral ventricle (Brain infusion kit 3; Durect Corporation). The cannula was connected to the micro-osmotic pump (model 1002; Durect Corporation) placed in the dorsal subcutaneous space of mice. The rate of delivery was $5 \mathrm{ng} / \mathrm{h}$ recombinant mouse leptin or aCSF. Seven days after the intracerebroventricular cannulation, mice were subjected to additional analysis.

Adrenalectomy and implantation of corticosterone pellet. Eight-weekold male C57BL/6J wild-type mice were anesthetized with isoflurane, and a cannula was implanted into the lateral ventricle. One week after the intracerebroventricular cannulation, mice were anesthetized with pentobarbital $(30 \mathrm{mg} / \mathrm{kg})$ and adrenalectomized and implanted with a $7.5 \mathrm{mg}$ corticosterone pellet (Innovation Research of America) or were sham operated. One week after the operation, the mice were subjected to additional experiments.

Blood glucose and serum analysis. Blood was sampled from the tail vein before being killed. Blood glucose concentrations were determined by the blood glucose test meter (Glutest PRO R; Sanwa-Kagaku). Serum leptin and corticosterone concentrations were determined by the commercially available enzyme-linked immunoassay kits (R \& D Systems and Assaypro, respectively).

Flow cytometry analysis. Flow cytometry analysis was performed to evaluate the B lineage cells in the bone marrow, mononuclear cells in the circulating blood, and splenocytes as described (Hashimoto et al., 2007; Kim-Saijo et al., 2008) using a FACSCalibur HG (BD Biosciences). The data were analyzed with BD CellQuest Pro (BD Biosciences). B cells were identified by anti-B220-APC, and their subpopulations were determined as follows: pro-B $\left(\mathrm{CD}_{3} 3^{+}\right.$, $\left.\mathrm{IgM}^{-}\right)$, pre-B $\left(\mathrm{CD} 43^{-}, \mathrm{IgM}^{-}\right)$, immature $\mathrm{B}\left(\operatorname{IgM}^{+}, \operatorname{IgD}^{\text {low }}\right)$, and mature $\mathrm{B}\left(\operatorname{IgM}^{+}, \operatorname{IgD}^{\text {high }}\right)$ cells (Claycombe et al., 2008).

Quantitative real-time PCR. Total RNA was extracted from the bone using Sepasol reagent, and quantitative real-time $\mathrm{PCR}$ was performed with an $\mathrm{ABI}$ Prism 7000 Sequence Detection System using PCR Master Mix Reagent (Applied Biosystems) as described (Suganami et al., 2005; Tanaka et al., 2010). Primers used to detect mRNAs are as follows: interleukin-7 (IL-7), forward, 5'-GGCACACAAACACTGGTGAACT- ${ }^{\prime}$ ' and reverse, $5^{\prime}$-TGCATCATTCTTTTTCTGTTCCTT-3'; stromal cell-derived factor-1 (SDF-1), forward, 5'-AGCCAACGTCAAGCATCTGA-3' and reverse, 5' TCGGGTCAATGCACACTTGT-3'; adiponectin, forward, 5' -ATGGCAGAGATGGCACTCCT- $3^{\prime}$ and reverse, $5^{\prime}$-CCTTCAGCTCCTGTCATTCCA-3'; and 36B4, forward, 5'-GGCCCTGCACTCTCGCTTTC-3' and reverse, $5^{\prime}$-TGCCAGGACGCGCTTGT- $3^{\prime}$. Levels of mRNA were normalized to those of 36B4 mRNA.

Statistical analysis. Data are presented as the mean \pm SEM, and $p<$ 0.05 and $p<0.01$ were considered statistically significant. Statistical analysis was performed using one-way ANOVA followed by TukeyKramer test.

\section{Results}

\section{Starvation-induced alteration of B-cell development in the bone marrow}

To investigate the effect of nutritional deprivation on B-cell development, we analyzed B lineage cells in the bone marrow of fasted mice. Food deprivation for up to $48 \mathrm{~h}$ significantly reduced body weight and blood glucose concentrations in C57BL/6J mice (Fig. 1 $A, B$ ). Serum leptin concentrations were markedly reduced after $24 \mathrm{~h}$ of food deprivation and almost undetectable at $48 \mathrm{~h}$ (Fig. 1C). FACS analysis revealed that the proportion of B220-positive cells (the whole B-cell compartment) in bone marrow cells tends to be decreased at $48 \mathrm{~h}$, but this trend did not reach statistical significance (Fig. 1D). In parallel with the decrease in serum leptin concentrations, the proportion of $\mathrm{B}$ lineage cells were markedly altered in the bone marrow of fasted mice; pro-B, pre- $\mathrm{B}$, and immature $\mathrm{B}$ cells were decreased, whereas mature B cells were increased (Fig. $1 E$ ). The proportion of B220-positive cells (mostly bone marrow-derived mature B cells) in splenocytes and mononuclear cells of the circulating blood tended to be decreased in fasted mice relative to ad libitum fed mice (Table 1). These observations together suggest that nutritional deprivation leads to the alteration of B-cell development in the bone marrow.

\section{Peripheral leptin administration prevents the starvation- induced alteration of B-cell development}

To explore the role of hypoleptinemia in the starvation-induced alteration of B-cell development in the bone marrow, C57BL/6J mice were administered intraperitoneally with recombinant mouse leptin twice daily during the starvation period. Intraperi- 

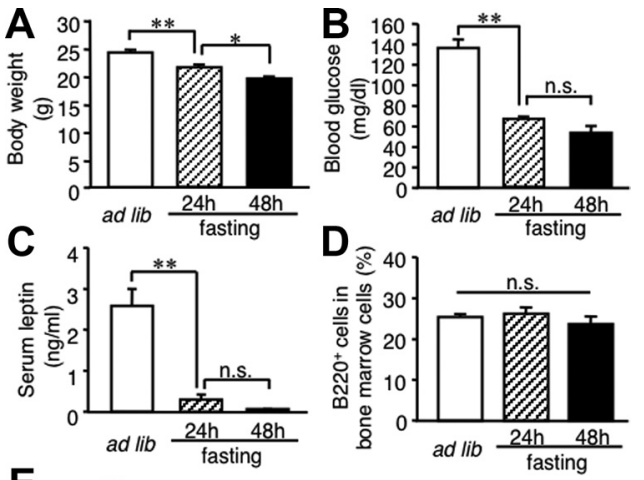

E

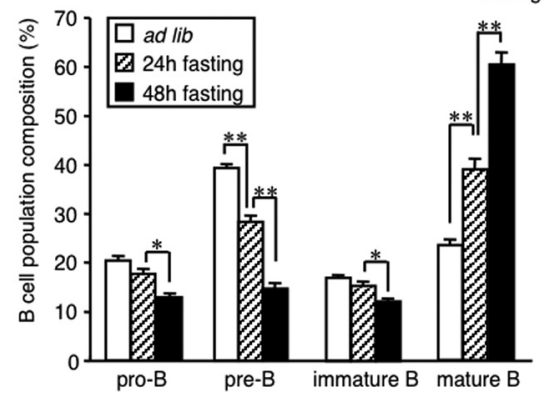

Figure 1. Effect of starvation on $B$ lineage cells in the bone marrow. Mice were deprived of chow for up to $48 \mathrm{~h}$. $\boldsymbol{A}-\boldsymbol{C}$, The effect of starvation on body weight $(\boldsymbol{A})$ and blood glucose $(\boldsymbol{B})$ and serum leptin $(\boldsymbol{C})$ concentrations. $\boldsymbol{D}, \boldsymbol{E}$, FACS analysis on the whole B-cell compartment $(\boldsymbol{D})$ and $B$ lineage cells $(\boldsymbol{E})$ in the bone marrow. Data in all graphs are mean \pm SEM. n.S., Not significant. ${ }^{*} p<0.05,{ }^{* *} p<0.01 ; n=5$.

Table 1. The proportion of $B$ cells in the spleen and circulating blood of fasted mice and ob/ob mice

\begin{tabular}{|c|c|c|}
\hline & \multicolumn{2}{|c|}{ Proportion of B220-positive cells } \\
\hline & $\%$ of splenocytes & $\begin{array}{l}\% \text { of mononuclear cells of } \\
\text { the circulating blood }\end{array}$ \\
\hline \multicolumn{3}{|l|}{ Wild type } \\
\hline Ad libitum & $56.6 \pm 1.2$ & $54.0 \pm 1.0$ \\
\hline Fasting & $50.4 \pm 2.1$ & $49.0 \pm 4.7$ \\
\hline \multicolumn{3}{|l|}{$o b / o b$} \\
\hline Ad libitum & $44.7 \pm 0.9^{*}$ & $42.3 \pm 2.7^{*}$ \\
\hline
\end{tabular}

The proportion of the B220-positive cells in splenocytes and mononuclear cells of the circulating blood of ad libitumfed wild-type, fasted wild-type, and ad libitum-fed ob/ob mice. Data are mean \pm SEM. ${ }^{*} p<0.05$ versus ad libitum-fed wild-type mice; $n=4$.

toneal injection of leptin did not affect body weight and tended to reduce blood glucose concentrations in fasted mice (Fig. $2 A, B$ ). In this study, serum leptin concentrations peaked at $1 \mathrm{~h}$ after the intraperitoneal injection of leptin and thereafter went down to the levels equivalent to those in mice fed ad libitum (Fig. 2C). There was no significant difference in serum leptin concentrations at $48 \mathrm{~h}$ between the fasted mice receiving leptin and PBS (Fig. 2D). The alteration of B lineage cells in the bone marrow of fasted mice was markedly prevented by peripheral leptin administration (Fig. 2 E). These observations suggest that leptin plays a critical role in the starvation-induced alteration of B-cell development in the bone marrow.

Central leptin administration prevents the starvationinduced alteration of B-cell development

Leptin is produced in the adipose tissue and is considered to regulate food intake and energy expenditure through the CNS, although the leptin receptor is expressed in a variety of peripheral tissues, including B cells (Papathanassoglou et al., 2006). To address whether leptin is capable of regulating B-cell development
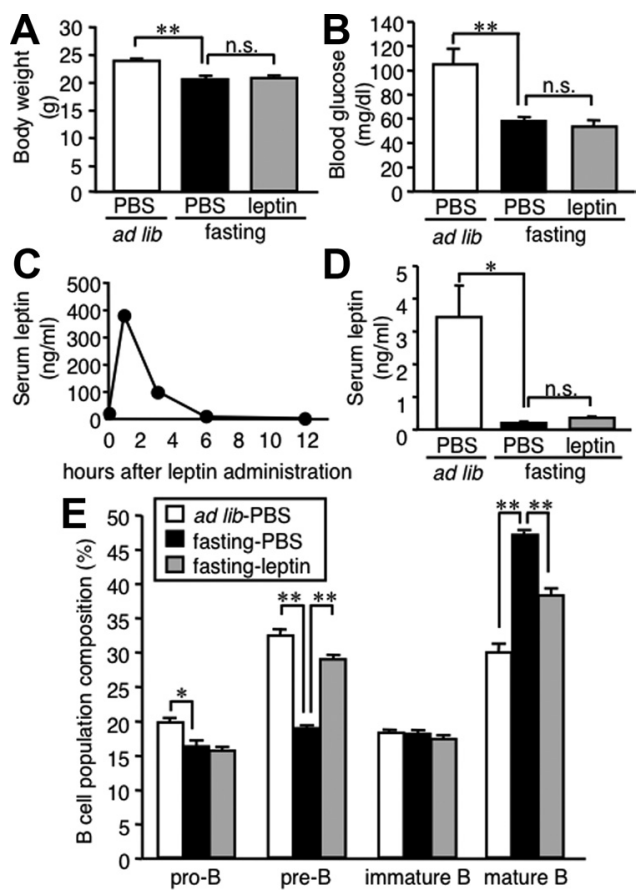

Figure 2. Effect of peripheral leptin administration on B lineage cells in the bone marrow offasted mice. Mice were divided into three groups: one group was allowed ad libitum access to chow with twice-a-day intraperitoneal injection of PBS, and two groups were deprived of chow for $48 \mathrm{~h}$ with twice-a-day intraperitoneal injection of recombinant mouse leptin $(1 \mu \mathrm{g} / \mathrm{g}$ initial body weight) or PBS. $\boldsymbol{A}, \boldsymbol{B}$, Body weight $(\boldsymbol{A})$ and blood glucose concentrations $(\boldsymbol{B})$ at $48 \mathrm{~h}$. $\boldsymbol{C}$, Time course of serum leptin concentrations after intraperitoneal injection of recombinant mouse leptin. $\boldsymbol{D}$, Serum leptin concentrations at the time the animals were killed. $E$, FACS analysis on the B lineage cells in the bone marrow. Data in all graphs are mean \pm SEM. n.S., Not significant. ${ }^{*} p<0.05,{ }^{* *} p<0.01 ; n=6-8$.
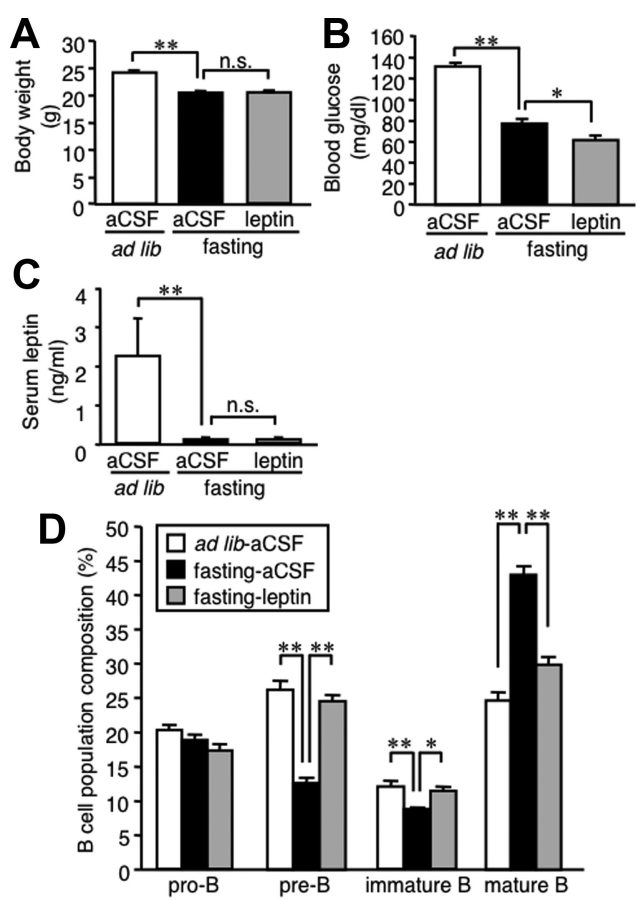

Figure 3. Effect of central leptin administration on B lineage cells in the bone marrow of fasted mice. Mice were divided into three groups: one group was allowed ad libitum access to chow with twice-a-day intracerebroventricular injection of aCSF, and two groups were deprived of chow for $48 \mathrm{~h}$ with twice-a-day intracerebroventricular injection of recombinant mouse leptin $(0.5 \mu \mathrm{g} / 0.5 \mu \mathrm{l})$ or aCSF. $\boldsymbol{A}-\boldsymbol{C}$, Body weight $(\boldsymbol{A})$ and blood glucose $(\boldsymbol{B})$ and serum leptin ( $\boldsymbol{C}$ concentrations at the time the animals were killed. $\boldsymbol{D}$, FACS analysis on the $B$ lineage cells in the bone marrow. Data in all graphs are mean \pm SEM. n.S., Not significant. ${ }^{*} p<0.05,{ }^{* *} p<0.01 ; n=6-8$. 
in the bone marrow via a central mechanism, we examined the effect of intracerebroventricular injection of recombinant mouse leptin on B lineage cells in the bone marrow. Intracerebroventricular injection of leptin did not affect body weight and significantly reduced blood glucose concentrations in fasted mice (Fig. $3 A, B)$. Serum leptin concentrations were unaffected by intracerebroventricular injection of leptin (Fig. $3 C$ ), suggesting no substantial leakage of exogenous leptin into the systemic circulation. Importantly, the alteration of B lineage cells in the bone marrow of fasted mice was markedly prevented by central leptin administration (Fig. 3D). These observations suggest that leptin is capable of affecting B-cell development in the bone marrow via a central mechanism.

Central leptin administration reverses the alteration of B-cell development in $o b / o b$ mice

To elucidate the long-term effect of leptin on B-cell development, we used leptin-deficient $o b / o b$ mice. As reported previously (Friedman and Halaas, 1998), 8-week-old male ob/ob mice exhibited marked obesity $(50.3 \pm 0.2 \mathrm{~g})$ and mild hyperglycemia $(266.5 \pm 22.4 \mathrm{mg} / \mathrm{dl})(n=4)$. In this study, the proportion of B220-positive cells in the splenocytes and circulating mononuclear cells was significantly reduced in $o b / o b$ mice relative to wildtype C57BL/6J mice (Table 1).

We next infused recombinant mouse leptin intracerebroventricularly to $o b / o b$ mice for $7 \mathrm{~d}$ using a micro-osmotic pump to examine the effect of central leptin administration on B lineage cells in the bone marrow. As reported previously (Friedman and Halaas, 1998), intracerebroventricular injection of leptin effectively decreased body weight and blood glucose concentrations in $o b / o b$ mice (Fig. 4A,B). The proportion of B220-positive cells in the bone marrow was significantly decreased in $o b / o b$ mice relative to wild-type mice (Fig. 4C). In this study, ob/ob mice exhibited the alteration of $\mathrm{B}$ lineage cell proportion in the bone marrow, which is similar to that in fasted wild-type mice (Figs. 1E, 4D). Such alteration in $o b / o b$ mice was almost completely reversed by intracerebroventricular injection of leptin (Fig. 4D), when there was no significant difference in the proportion of B220positive cells between the $o b / o b$ mice receiving leptin and aCSF (Fig. 4C). These observations together suggest that central leptin administration reverses the alteration of B-cell development in the bone marrow of leptin-deficient $o b / o b$ mice.

\section{IL-7, SDF-1, and adiponectin do not play a major role in the starvation- induced alteration of B-cell development}

To obtain insight into the mechanism underlying the starvation-induced alteration of B-cell development in the bone marrow, we examined mRNA expression of IL-7, SDF-1 (also called CXCL12), and adiponectin in the bone. IL-7 and SDF-1 are known to be derived from osteoblasts, thereby regulating B-cell development in the bone marrow (Tokoyoda et al., 2004). It is also known that adiponectin, a major adipocytokine, potently inhibits B-cell development (Yokota et al., 2003). In this study, we did not observe significant differences in IL-7, SDF-1, and
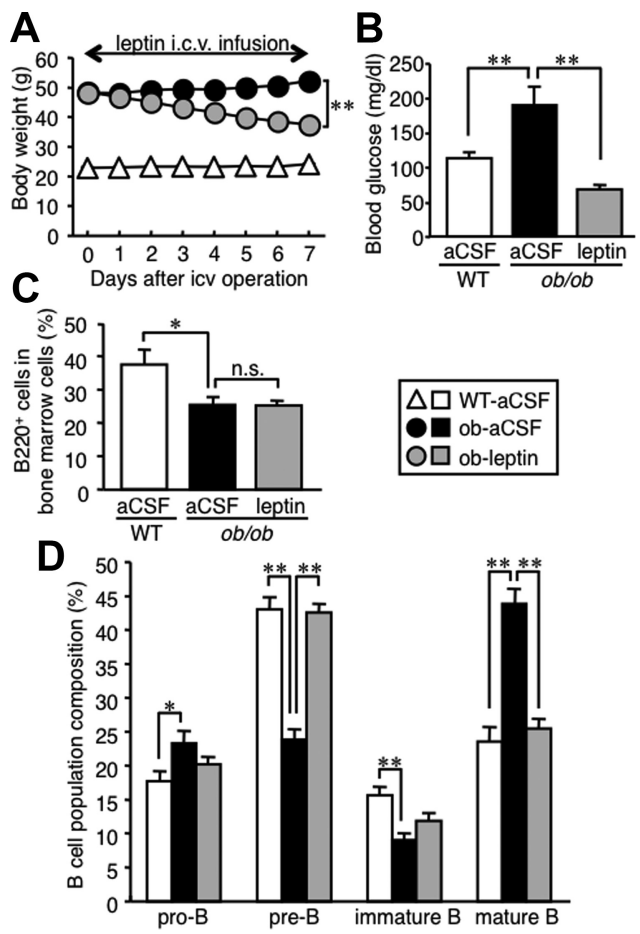

Figure 4. Effect of central leptin administration on B lineage cells in the bone marrow of $o b / o b$ mice. Mice received continuous intracerebroventricular (icv) injection with leptin ( $5 \mathrm{ng} / \mathrm{h}$ ) or aCSF for $7 \mathrm{~d}$. $\boldsymbol{A}$, Time course of body weight change. $\boldsymbol{B}$, Blood glucose concentrations at day 7 . $\boldsymbol{C}, \boldsymbol{D}$, FACS analysis on the whole B-cell compartment $(\boldsymbol{C})$ and $B$ lineage cells $(\boldsymbol{D})$ in the bone marrow. Data in all graphs are mean \pm SEM. WT, Wild type; n.S., not significant. ${ }^{*} p<0.05$, ${ }^{* *} p<0.01 ; n=6$.
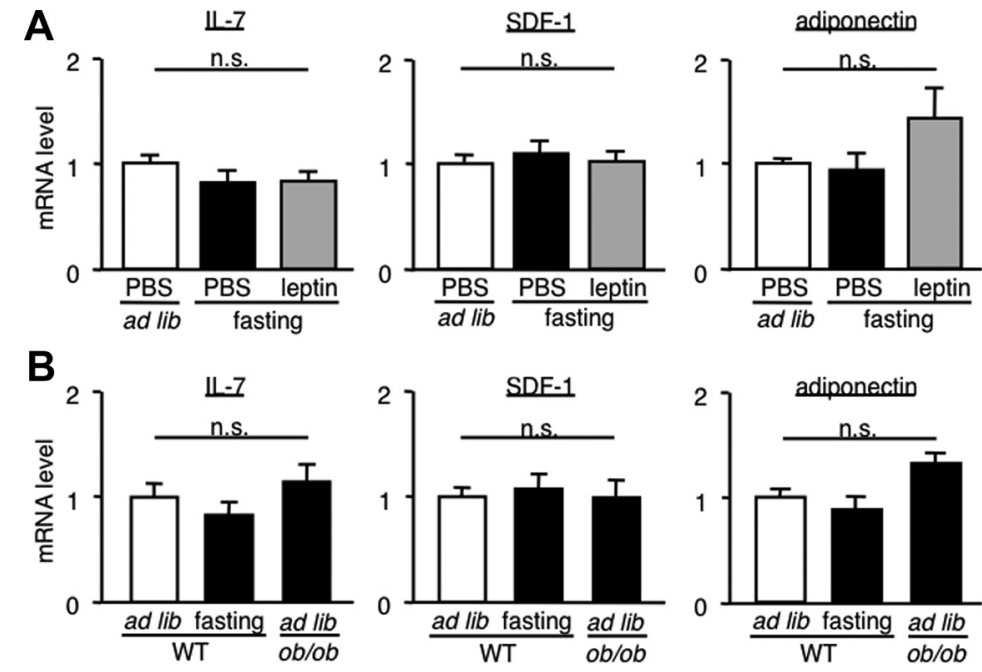

Figure 5. IL-7, SDF-1, and adiponectin mRNA expression in the bone of fasted mice and $o b / o b$ mice. $\boldsymbol{A}$, Effect of intraperitoneal leptin injection on IL-7, SDF-1, and adiponectin mRNA expression of in the bone of wild-type mice. $B, I L-7$, SDF-1, and adiponectin mRNA expression of in the bone of $o b / 0 b$ and wild-type mice. Mice were deprived of chow for $48 \mathrm{~h}$ or fed ad libitum. Data in all graphs are mean \pm SEM. WT, Wild type; n.s., not significant. $n=4$. adiponectin mRNA expression between ad libitum-fed wild-type, fasted wild-type, and fasted wild-type receiving intraperitoneal injection of leptin (Fig. 5A). We also observed no significant differences in IL-7, SDF-1, and adiponectin mRNA expression among ad libitum-fed wild-type, fasted wild-type, and ad libitumfed ob/ob mice (Fig. 5B). 
A
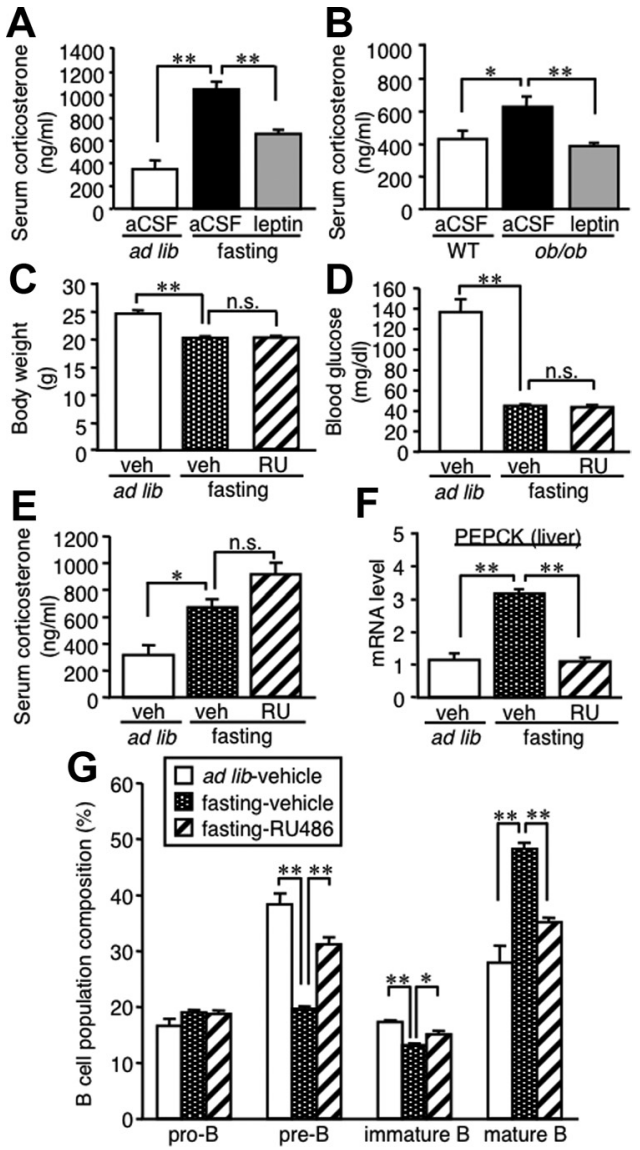

Figure 6. Role of corticosterone in the starvation-induced alteration of B-cell development in the bone marrow. $\boldsymbol{A}, \boldsymbol{B}$, Effect of intracerebroventricular leptin injection on serum corticosterone concentrations in fasted mice $(\boldsymbol{A})$ and $0 b / 0 b$ mice $(\boldsymbol{B})$. Mice were deprived of chow for $48 \mathrm{~h}$ with twice-a-day intracerebroventricular injection of recombinant mouse leptin $(0.5 \mu \mathrm{g} / 0.5 \mu \mathrm{l})$ or aCSF $(\boldsymbol{A})$. Mice received continuous intracerebroventricular injection with leptin ( $5 \mathrm{ng} / \mathrm{h})$ or aCSF for $7 \mathrm{~d}(\boldsymbol{B})$. C - G, Effect of RU486, a glucocorticoid receptor antagonist, on B lineage cells in the bone marrow of fasted mice. Mice were deprived of chow for $48 \mathrm{~h}$ with twice-a-day oral administration of RU486 (25 $\mu \mathrm{g} / \mathrm{g}$ initial body weight) or vehicle. $\boldsymbol{C}$, Body weight; $\boldsymbol{D}$, blood glucose concentration; $\boldsymbol{E}$, serum corticosterone concentrations. F, PEPCK mRNA expression in the liver. G, FACS analysis on B lineage cells in the bone marrow. WT, Wild type; veh, vehicle; RU, RU486; n.S., not significant. Data in all graphs are mean \pm SEM. ${ }^{*} p<0.05,{ }^{* *} p<0.01 ; n=4-6$.

Corticosterone plays a role in the starvation-induced alteration of B-cell development

Because starvation increases corticosterone production as a physiologic adaptation to energy deprivation through the activation of the hypothalamus-pituitary-adrenal axis (Ahima et al., 1996; Chan and Mantzoros, 2005), we examined the role of corticosterone in the starvation-induced alteration of B-cell development. In this study, intracerebroventricular injection of leptin significantly prevented the increase in serum corticosterone concentrations in fasted mice and $o b / o b$ mice (Fig. 6A,B). To explore the functional significance of corticosterone, we examined the effect of RU486 (11 $\beta$-[p-(dimethylamino)phenyl]-17 $\beta$-hydroxy-17(1-propynyl)estra-4,9-dien-3-one), a glucocorticoid receptor antagonist, on the starvation-induced alteration of B-cell development. Oral administration of RU486 did not affect body weight and blood glucose and serum corticosterone concentrations during the starvation period (Fig. $6 C-E$ ). Similar to the previous report that RU486 administration suppresses the otherwise increased phosphoenolpyruvate carboxykinase (PEPCK) mRNA expression in the liver of $d b / d b$ mice with leptin receptor

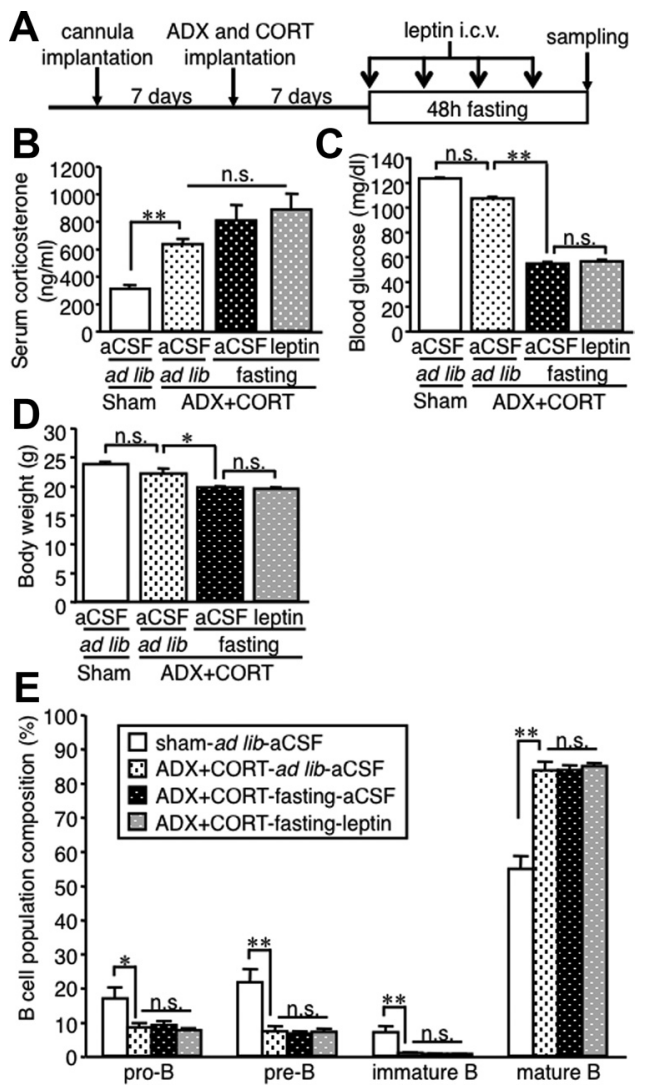

Figure 7. Effect of leptin in the starvation-induced alteration of B-cell development in the bone marrow of adrenalectomized mice. $\boldsymbol{A}$, Experimental protocol. Adrenalectomized mice with subcutaneous implantation of corticosterone pellet $(7.5 \mathrm{mg} /$ pellet per mouse) were deprived of chow for $48 \mathrm{~h}$ with twice-a-day intracerebroventricular injection of recombinant mouse leptin $(0.5 \mu \mathrm{g} / 0.5 \mu \mathrm{l})$ or aCSF. $\boldsymbol{B}$ - $\boldsymbol{D}$, Serum corticosterone $(\boldsymbol{B})$ and blood glucose $(\boldsymbol{C})$ concentrations and body weight $(\boldsymbol{D})$ at the time the animals were killed. $\boldsymbol{E}$, FACS analysis on the B lineage cells in the bone marrow. ADX, Adrenalectomy; CORT, corticosterone pellet; icv, intracerebroventricular; n.S., not significant. Data in all graphs are mean \pm SEM. ${ }^{*} p<0.05,{ }^{* *} p<0.01 ; n=4-5$.

defect (Liu et al., 2005), the starvation-induced PEPCK mRNA expression was effectively suppressed by RU486 (Fig. 6 F). In this setting, the alteration of $\mathrm{B}$ lineage cell proportion in the bone marrow of fasted mice was markedly prevented by RU486 administration (Fig. 6G).

We further examined the connection between central leptin signaling, corticosterone, and B-cell development using adrenalectomized mice with implantation of corticosterone pellet (Fig. 7A). In this study, serum corticosterone concentrations were mostly comparable with those in fasted mice (Figs. $6 A, E, 7 B$ ). Starvation and central leptin administration did not affect serum corticosterone and blood glucose concentrations and body weight (Fig. $7 B-D$ ). In this setting, the adrenalectomized mice showed $\mathrm{B}$ lineage cell proportion in the bone marrow, which is similar to those in fasted mice (Figs. 1E, 7E). Moreover, we observed no significant difference in $\mathrm{B}$ lineage cells among the three groups with adrenalectomy: ad libitumfed mice, fasted mice, and fasted mice with intracerebroventricular leptin injection. These observations together suggest that corticosterone plays an important role in the regulation of B-cell development under starvation conditions.

\section{NPY plays a role in the starvation-induced alteration of B-cell development}

Because it is known that NPY, when increased in the hypothalamus under starvation conditions, contributes to increased corti- 


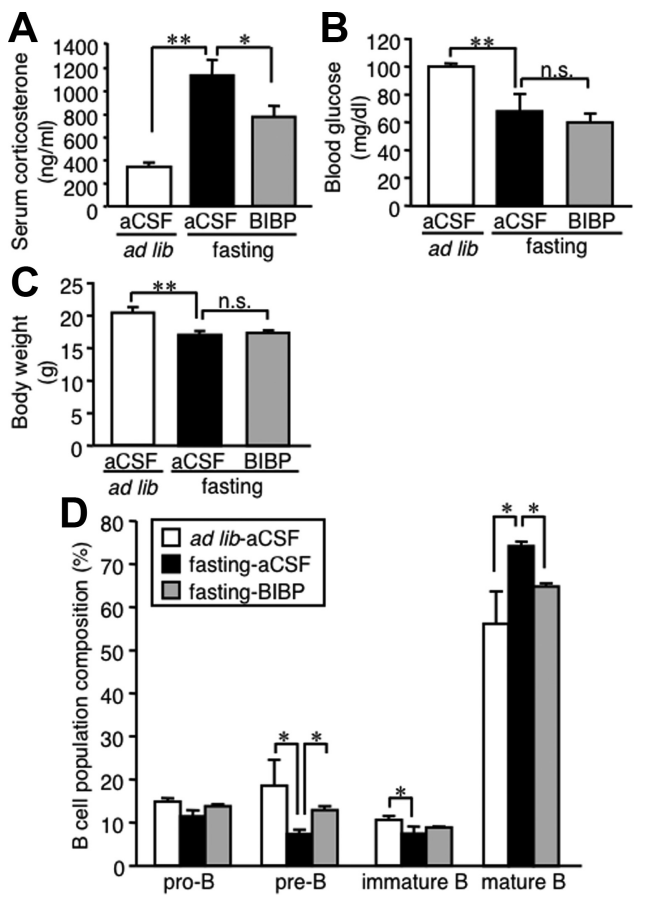

Figure 8. Effect of central administration of $Y_{1} R$ antagonist on $B$ lineage cells in the bone marrow of fasted mice. Mice were deprived of chow for $48 \mathrm{~h}$ with twice-a-day intracerebroventricular injection of the $Y_{1} R$ antagonist BIBP3226 $(10 \mathrm{nmol} / 0.5 \mu \mathrm{l})$ or aCSF. $A-C$, Serum corticosterone $(\boldsymbol{A})$ and blood glucose $(\boldsymbol{B})$ concentrations and body weight $(\boldsymbol{C})$ at the time the animals were killed. D, FACS analysis on the B lineage cells in the bone marrow. BIBP, BIBP3226; n.S., not significant. Data in all graphs are mean \pm SEM. ${ }^{*} p<0.05,{ }^{* *} p<0.01 ; n=4-5$.

costerone production (Luque et al., 2007), we next examined the effect of BIBP3226, a $\mathrm{Y}_{1} \mathrm{R}$ antagonist, on the regulation of B-cell development. Intracerebroventricular injection of BIBP3226 significantly reduced serum corticosterone concentrations in fasted mice, whereas there were no significant changes in blood glucose concentrations and body weight (Fig. $8 A-C$ ). In this setting, the alteration of $B$ lineage cell proportion in the bone marrow of fasted mice was markedly prevented by intracerebroventricular BIBP3226 injection (Fig. 8D). These observations suggest that the NPY $-Y_{1} R$ pathway plays a role in the starvation-induced hypercorticosteronemia and alteration of B-cell development.

\section{Discussion}

It is known that nutritional deprivation or malnutrition leads to immune suppression in humans and animals (Cason et al., 1986; Chandra, 1991; Lord et al., 1998; Chan et al., 2006). Here, we provided evidence that B-cell development in the bone marrow is altered by nutritional deprivation in parallel with decreased serum leptin concentrations. Importantly, intraperitoneal injection of recombinant leptin effectively prevented the alteration of B-cell development in the bone marrow of fasted mice. In this regard, Claycombe et al. (2008) reported that ob/ob mice exhibit impaired B lymphopoiesis in the bone marrow relative to wildtype mice. These observations together suggest that hypoleptinemia plays a critical role in the starvation-induced alteration of $\mathrm{B}$-cell development. This discussion is consistent with the previous report by Chan et al. (2006) that $72 \mathrm{~h}$ fasting significantly reduces the $\mathrm{B}$-cell population in the circulating blood of healthy humans, which is partly prevented by subcutaneous injection of recombinant human leptin (Chan et al., 2006). Unlike fasted mice, ob/ob mice exhibited marked obesity and high blood glucose concentrations, although they both developed the alteration
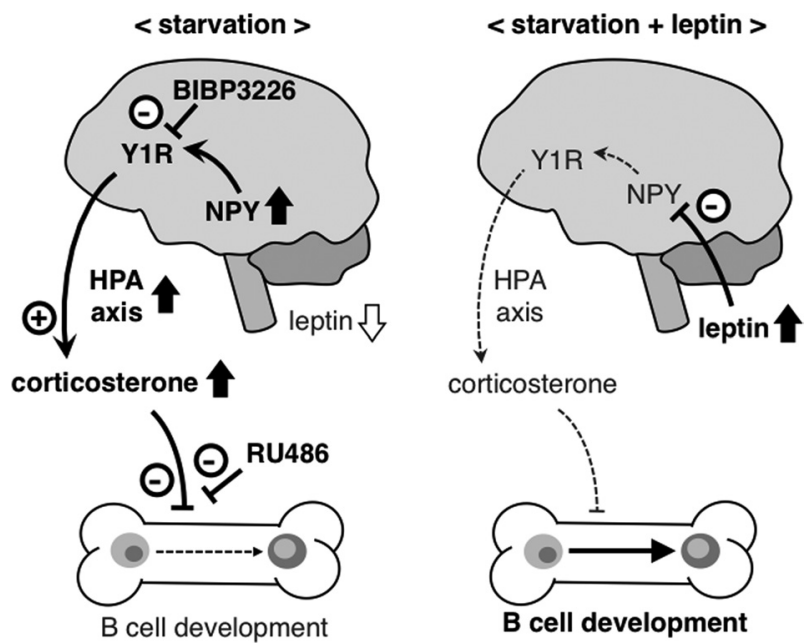

Figure 9. Potential mechanism of the leptin-mediated regulation of B-cell development in the bone marrow under starvation conditions. Under starvation conditions, activation of the NPY $-Y_{1} R$ pathway in the CNS as a result of hypoleptinemia plays an important role in the alteration of B-cell development in the bone marrow, at least partly through increased production of corticosterone. Central leptin administration effectively reverses the starvation-induced alteration of B-cell development, probably through suppressing the NPY-Y $Y_{1} R$ pathway and corticosterone production. HPA axis, Hypothalamus-pituitary-adrenal axis.

of B-cell development. Moreover, leptin did not affect body weight and blood glucose concentrations in fasted mice, which is consistent with a previous report (Ahima et al., 1996). These observations suggest that leptin regulates B-cell development and energy metabolism via different mechanisms. Conversely, evidence has suggested the role of leptin in the starvation-induced thymic atrophy and T-cell apoptosis (Lord et al., 1998; Howard et al., 1999). Because leptin is produced in the adipose tissue in response to the nutritional change, the data of this study support the concept that leptin acts as a nutritional sensor to regulate the acquired immune system. Thus, the leptin-mediated alteration of B-cell development may be relevant to the immune dysfunction in energy-deprivation states, such as anorexia nervosa, malnutrition, or cachexia.

Because leptin receptor is expressed in a variety of central and peripheral tissues and cells including $\mathrm{T}$ and $\mathrm{B}$ cells, it is important to know whether leptin can regulate B-cell development in the bone marrow via central and/or peripheral mechanisms. It is reported that B cells from mouse spleen are protected from Fasmediated apoptosis in vitro when treated with recombinant leptin (Palmer et al., 2006). Leptin also promotes survival of B cells from the spleen via induction of B-cell CLL/lymphoma (Bcl-2) and cyclin D1 (Lam et al., 2010). Conversely, there is considerable in vivo evidence that central leptin signaling is sufficient for its effect on energy and glucose homeostasis and even locomotor activity (Coppari et al., 2005; de Luca et al., 2005). In this study, we demonstrated for the first time that central leptin administration effectively prevents the alteration of B-cell development in the bone marrow of fasted mice and $o b / o b$ mice. This is reminiscent of our recent observation that central leptin administration in $o b / o b$ mice reverses the otherwise reduced macrophage infiltration in a mouse model of renal injury (Tanaka et al., 2010). Similarly, Tschöp et al. (2010) reported that central leptin administration increases survival during sepsis in $o b / o b$ mice as well as wild-type mice. Although our data do not rule out the possibility that leptin acts directly on B cells to regulate their development, it is likely that central leptin signaling plays a major role in B-cell 
development in the bone marrow in vivo under starvation conditions.

It is also important to understand how central leptin signaling regulates $\mathrm{B}$-cell development. Leptin plays a critical role in the neuroendocrine response to fasting such as the hypothalamuspituitary-adrenal axis (Ahima et al., 1996; Chan and Mantzoros, 2005). Laakko and Fraker (2002) previously reported that subcutaneous implantation of corticosterone pellets into wild-type mice results in the alteration of B-cell development in the bone marrow, which is similar to that in fasted mice. These findings led us to speculate the role of corticosterone in the starvationinduced alteration of B-cell development. In this study, we observed that serum corticosterone concentrations are markedly increased short and long term of leptin deficiency (corresponding to fasted wild-type mice and $o b / o b$ mice, respectively), which is effectively suppressed by central leptin administration as reported previously (Ahima et al., 1996; Huang et al., 1998). Importantly, administration of a glucocorticoid receptor antagonist to fasted mice markedly prevented the alteration of B-cell development in the bone marrow. Moreover, we confirmed that the proportion of $\mathrm{B}$ lineage cells in the bone marrow is not affected by starvation and central leptin administration in adrenalectomized mice, when serum corticosterone concentrations are unaltered. These observations support the concept that corticosterone plays an important role in the alteration of B-cell development under starvation conditions. Although central leptin signaling regulates bone formation via the sympathetic nervous system, in which $\beta_{2}$-adrenargic receptor ( $\left.a d r b 2\right)$ expressed on osteoblasts may play an important role (Elefteriou et al., 2005), we observed no significant difference in B lineage cells in the bone marrow between $a d r b 2-d e f i c i e n t$ and wild-type mice (M. Tanaka, T. Soganami, and Y. Ogawa, unpublished observations). Additional studies are required to elucidate the involvement of humoral and neuronal mechanisms in the alteration of B-cell development in the bone marrow under starvation conditions.

It is known that NPY, when increased in the hypothalamus under starvation conditions, stimulates potently food intake mainly through $\mathrm{Y}_{1} \mathrm{R}$ (Pedrazzini et al., 1998; Kanatani et al., 2000; Lin et al., 2004). The NPY-Y $\mathrm{R}_{1}$ pathway in the CNS also plays a role in the regulation of blood pressure and the hypothalamuspituitary-adrenal axis (Pedrazzini et al., 1998; Dimitrov et al., 2007). In this study, we demonstrated that intracerebroventricular injection of a $\mathrm{Y}_{1} \mathrm{R}$ antagonist significantly prevents the starvation-induced hypercorticosteronemia and alteration of B-cell development in the bone marrow. Of note, the starvationinduced upregulation of NPY in the hypothalamus is effectively suppressed by leptin injection (Ahima et al., 1999; ShimizuAlbergine et al., 2001; Jovanovic et al., 2010). It is, therefore, conceivable that the NPY-Y ${ }_{1} \mathrm{R}$ pathway is involved in the leptinmediated regulation of $\mathrm{B}$-cell development in the bone marrow, at least partly through increased production of corticosterone. Additional studies are required to elucidate the role of the NPY$\mathrm{Y}_{1} \mathrm{R}$ pathway in B-cell development independent of the hypothalamus-pituitary-adrenal axis. In this study, the proportion of $\mathrm{B}$ cells in splenocytes and circulating blood mononuclear cells was not statistically decreased after $48 \mathrm{~h}$ fasting, which may be, at least in part, attributable to the long (5-6 weeks) half-life of mature B cells (Abbas and Lichtman, 2003). Indeed, ob/ob mice exhibited a marked decrease in the proportion of $B$ cells in the spleen and circulating blood relative to wild-type mice, suggesting that the long-term nutritional deprivation leads to the decrease in the B-cell population in the spleen and circulating blood. It is known that early B-cell development (pro-B, pre-B, and immature B cells) is confined to the bone marrow (Hardy et al., 1991). Some immature B cells then leave the bone marrow to mature in the spleen, whereas others remain in the bone marrow for maturation (Cariappa et al., 2007). It is also known that mature B cells in the spleen recirculate into the bone marrow (Cariappa et al., 2005; Cinamon et al., 2008). In this study, we observed that the proportion of mature B cells in the bone marrow is significantly elevated in fasted mice and $o b / o b$ mice, which is in contrast to that in spleen. Because mature B cells in the bone marrow can participate in humoral immune responses to microbes similar to those in the spleen (Cariappa et al., 2005), it would be interesting to know the functional difference of B cells between the bone marrow and spleen under leptin-deficient conditions.

In conclusion, this study provides the first in vivo evidence for the role of central leptin signaling in the starvation-induced alteration of B-cell development in the bone marrow (Fig. 9). The data of this study suggest that the CNS, which is inherent to integrate information from throughout the organism, is able to control immune function.

\section{References}

Abbas AK, Lichtman AH (2003) Cellular and molecular immunology, Ed 5, pp 16-39. Philadelphia: Saunders.

Ahima RS, Prabakaran D, Mantzoros C, Qu D, Lowell B, Maratos-Flier E, Flier JS (1996) Role of leptin in the neuroendocrine response to fasting. Nature 382:250-252.

Ahima RS, Kelly J, Elmquist JK, Flier JS (1999) Distinct physiologic and neuronal responses to decreased leptin and mild hyperleptinemia. Endocrinology 140:4923-4931.

Bodary PF, Shen Y, Ohman M, Bahrou KL, Vargas FB, Cudney SS, Wickenheiser KJ, Myers MG Jr, Eitzman DT (2007) Leptin regulates neointima formation after arterial injury through mechanisms independent of blood pressure and the leptin receptor/STAT3 signaling pathways involved in energy balance. Arterioscler Thromb Vasc Biol 27:70-76.

Busso N, So A, Chobaz-Péclat V, Morard C, Martinez-Soria E, Talabot-Ayer D, Gabay C (2002) Leptin signaling deficiency impairs humoral and cellular immune responses and attenuates experimental arthritis. J Immunol $168: 875-882$.

Cariappa A, Mazo IB, Chase C, Shi HN, Liu H, Li Q, Rose H, Leung H, Cherayil BJ, Russell P, von Andrian U, Pillai S (2005) Perisinusoidal B cells in the bone marrow participate in T-independent responses to blood-borne microbes. Immunity 23:397-407.

Cariappa A, Chase C, Liu H, Russell P, Pillai S (2007) Naive recirculating B cells mature simultaneously in the spleen and bone marrow. Blood 109:2339-2345.

Cason J, Ainley CC, Wolstencroft RA, Norton KR, Thompson RP (1986) Cell-mediated immunity in anorexia nervosa. Clin Exp Immunol 64:370-375.

Chan JL, Mantzoros CS (2005) Role of leptin in energy-deprivation states: normal human physiology and clinical implications for hypothalamic amenorrhoea and anorexia nervosa. Lancet 366:74-85.

Chan JL, Matarese G, Shetty GK, Raciti P, Kelesidis I, Aufiero D, De Rosa V, Perna F, Fontana S, Mantzoros CS (2006) Differential regulation of metabolic, neuroendocrine, and immune function by leptin in humans. Proc Natl Acad Sci U S A 103:8481-8486.

Chandra RK (1991) 1990 McCollum Award lecture. Nutrition and immunity: lessons from the past and new insights into the future. Am J Clin Nutr 53:1087-1101.

Cinamon G, Zachariah MA, Lam OM, Foss FW Jr, Cyster JG (2008) Follicular shuttling of marginal zone B cells facilitates antigen transport. Nat Immunol 9:54-62.

Claycombe K, King LE, Fraker PJ (2008) A role for leptin in sustaining lymphopoiesis and myelopoiesis. Proc Natl Acad Sci USA 105:2017-2021.

Cone RD (2006) Studies on the physiological functions of the melanocortin system. Endocr Rev 27:736-749.

Coppari R, Ichinose M, Lee CE, Pullen AE, Kenny CD, McGovern RA, Tang V, Liu SM, Ludwig T, Chua SC Jr, Lowell BB, Elmquist JK (2005) The 
hypothalamic arcuate nucleus: a key site for mediating leptin's effects on glucose homeostasis and locomotor activity. Cell Metab 1:63-72.

de Luca C, Kowalski TJ, Zhang Y, Elmquist JK, Lee C, Kilimann MW, Ludwig T, Liu SM, Chua SC Jr (2005) Complete rescue of obesity, diabetes, and infertility in $d b / d b$ mice by neuron-specific LEPR-B transgenes. J Clin Invest 115:3484-3493.

Dimitrov EL, DeJoseph MR, Brownfield MS, Urban JH (2007) Involvement of neuropeptide Y Y1 receptors in the regulation of neuroendocrine corticotropin-releasing hormone neuronal activity. Endocrinology 148:3666-3673.

Elefteriou F, Ahn JD, Takeda S, Starbuck M, Yang X, Liu X, Kondo H, Richards WG, Bannon TW, Noda M, Clement K, Vaisse C, Karsenty G (2005) Leptin regulation of bone resorption by the sympathetic nervous system and CART. Nature 434:514-520.

Friedman JM, Halaas JL (1998) Leptin and the regulation of body weight in mammals. Nature 395:763-770.

Hardy RR, Carmack CE, Shinton SA, Kemp JD, Hayakawa K (1991) Resolution and characterization of pro-B and pre-pro-B cell stages in normal mouse bone marrow. J Exp Med 173:1213-1225.

Hashimoto K, Fujimoto T, Shimoda Y, Huang X, Sakamoto H, Ogawa M (2007) Distinct hemogenic potential of endothelial cells and CD41 ${ }^{+}$cells in mouse embryos. Dev Growth Differ 49:287-300.

Howard JK, Lord GM, Matarese G, Vendetti S, Ghatei MA, Ritter MA, Lechler RI, Bloom SR (1999) Leptin protects mice from starvation-induced lymphoid atrophy and increases thymic cellularity in $o b / o b$ mice. J Clin Invest 104:1051-1059.

Huang Q, Rivest R, Richard D (1998) Effects of leptin on corticotropinreleasing factor (CRF) synthesis and CRF neuron activation in the paraventricular hypothalamic nucleus of obese $(o b / o b)$ mice. Endocrinology 139:1524-1532.

Jovanovic Z, Tung YC, Lam BY, O'Rahilly S, Yeo GS (2010) Identification of the global transcriptomic response of the hypothalamic arcuate nucleus to fasting and leptin. J Neuroendocrinol 22:915-925.

Kanatani A, Mashiko S, Murai N, Sugimoto N, Ito J, Fukuroda T, Fukami T, Morin N, MacNeil DJ, Van der Ploeg LH, Saga Y, Nishimura S, Ihara M (2000) Role of the Y1 receptor in the regulation of neuropeptide Y-mediated feeding: comparison of wild-type, $\mathrm{Y} 1$ receptor-deficient, and Y5 receptor-deficient mice. Endocrinology 141:1011-1016.

Kim-Saijo M, Janssen EM, Sugie K (2008) CD4 cell-secreted, posttranslationally modified cytokine GIF suppresses Th2 responses by inhibiting the initiation of IL-4 production. Proc Natl Acad Sci U S A 105: 19402-19407.

Laakko T, Fraker P (2002) Rapid changes in the lymphopoietic and granulopoietic compartments of the marrow caused by stress levels of corticosterone. Immunology 105:111-119.

La Cava A, Matarese G (2004) The weight of leptin in immunity. Nat Rev Immunol 4:371-379.

Lam QL, Wang S, Ko OK, Kincade PW, Lu L (2010) Leptin signaling maintains B-cell homeostasis via induction of Bcl-2 and Cyclin D1. Proc Natl Acad Sci U S A 107:13812-13817.

Lin S, Boey D, Herzog H (2004) NPY and Y receptors: lessons from transgenic and knockout models. Neuropeptides 38:189-200.

Liu Y, Nakagawa Y, Wang Y, Sakurai R, Tripathi PV, Lutfy K, Friedman TC (2005) Increased glucocorticoid receptor and $11 \beta$-hydroxysteroid dehy- drogenase type 1 expression in hepatocytes may contribute to the phenotype of type 2 diabetes in $d b / d b$ mice. Diabetes 54:32-40.

Lord GM, Matarese G, Howard JK, Baker RJ, Bloom SR, Lechler RI (1998) Leptin modulates the T-cell immune response and reverses starvationinduced immunosuppression. Nature 394:897-901.

Luque RM, Park S, Kineman RD (2007) Severity of the catabolic condition differentially modulates hypothalamic expression of growth hormonereleasing hormone in the fasted mouse: potential role of neuropeptide $Y$ and corticotropin-releasing hormone. Endocrinology 148:300-309.

Ogawa Y, Masuzaki H, Hosoda K, Aizawa-Abe M, Suga J, Suda M, Ebihara K, Iwai H, Matsuoka N, Satoh N, Odaka H, Kasuga H, Fujisawa Y, Inoue G, Nishimura H, Yoshimasa Y, Nakao K (1999) Increased glucose metabolism and insulin sensitivity in transgenic skinny mice overexpressing leptin. Diabetes 48:1822-1829.

Palmer G, Aurrand-Lions M, Contassot E, Talabot-Ayer D, Ducrest-Gay D, Vesin C, Chobaz-Péclat V, Busso N, Gabay C (2006) Indirect effects of leptin receptor deficiency on lymphocyte populations and immune response in $d b / d b$ mice. J Immunol 177:2899-2907.

Papathanassoglou E, El-Haschimi K, Li XC, Matarese G, Strom T, Mantzoros C (2006) Leptin receptor expression and signaling in lymphocytes: kinetics during lymphocyte activation, role in lymphocyte survival, and response to high fat diet in mice. J Immunol 176:7745-7752.

Pedrazzini T, Seydoux J, Künstner P, Aubert JF, Grouzmann E, Beermann F, Brunner HR (1998) Cardiovascular response, feeding behavior and locomotor activity in mice lacking the NPY Y1 receptor. Nat Med 4:722-726.

Satoh N, Ogawa Y, Katsuura G, Numata Y, Masuzaki H, Yoshimasa Y, Nakao K (1998) Satiety effect and sympathetic activation of leptin are mediated by hypothalamic melanocortin system. Neurosci Lett 249:107-110.

Shimizu-Albergine M, Ippolito DL, Beavo JA (2001) Downregulation of fasting-induced cAMP response element-mediated gene induction by leptin in neuropeptide $\mathrm{Y}$ neurons of the arcuate nucleus. J Neurosci 21:1238-1246.

Suganami T, Nishida J, Ogawa Y (2005) A paracrine loop between adipocytes and macrophages aggravates inflammatory changes: role of free fatty acids and tumor necrosis factor $\alpha$. Arterioscler Thromb Vasc Biol 25:2062-2068.

Tanaka M, Suganami T, Sugita S, Shimoda Y, Kasahara M, Aoe S, Takeya M, Takeda S, Kamei Y, Ogawa Y (2010) Role of central leptin signaling in renal macrophage infiltration. Endocr J 57:61-72.

Tokoyoda K, Egawa T, Sugiyama T, Choi BI, Nagasawa T (2004) Cellular niches controlling B lymphocyte behavior within bone marrow during development. Immunity 20:707-718.

Tschöp J, Nogueiras R, Haas-Lockie S, Kasten KR, Castañeda TR, Huber N, Guanciale K, Perez-Tilve D, Habegger K, Ottaway N, Woods SC, Oldfield B, Clarke I, Chua S Jr, Farooqi IS, O’Rahilly S, Caldwell CC, Tschöp MH (2010) leptin action modulates immune response and survival in sepsis. J Neurosci 30:6036-6047.

Yokota T, Meka CS, Kouro T, Medina KL, Igarashi H, Takahashi M, Oritani K, Funahashi T, Tomiyama Y, Matsuzawa Y, Kincade PW (2003) Adiponectin, a fat cell product, influences the earliest lymphocyte precursors in bone marrow cultures by activation of the cyclooxygenaseprostaglandin pathway in stromal cells. J Immunol 171:5091-5099. 